\title{
Childhood Anaplastic Large Cell Lymphoma
}

National Cancer Institute

\section{Source}

National Cancer Institute. Childhood Anaplastic Large Cell Lymphoma. NCI Thesaurus.

Code C5636.

An anaplastic large cell lymphoma that occurs during childhood. 